\title{
Spatial distribution and sources of polycyclic aromatic hydrocarbons (PAHs) in green mussels (Perna viridis) from coastal areas of Peninsular Malaysia: implications for source identification of perylene
}

\begin{abstract}
Distribution of polycyclic aromatic hydrocarbons (PAHs) was determined in green mussels (Perna viridis) from various sites in coastal waters of Peninsular Malaysia between August 2004 and January 2007, in order to assess contamination by petroleum hydrocarbons. The range of $\times$ PAHs detected in mussels was from 766 to 110500 (ng/g lipid wt.). High concentrations of PAHs were found in mussel tissues collected near Penang Bridge. The ratios of methyl phenanthrenes to phenanthrene ( $\times \mathrm{MP} / \mathrm{P}$ ratio) for Penang, Kg. Pasir Puteh and Tebing Runtuh (Johore Straits) were greater than 2, indicating extensive input of petrogenic PAHs. The results indicated that male individuals elevated more considerable concentrations of PAHs in their soft tissues in comparison to female individuals. The results of independent sample T-test showed that there were no significant differences $(p>0.05)$ between male and female mussels analysed in the Pasir Panjang station. Negative significant correlations $(r=i 0.890, p<0.01)$ and $(r=i 0.0655, p<0.05)$, were found between weight and total of PAHs in female and male species, respectively. This indicated that body weight of each individual was not affected by the PAHs concentrations. The present study proposes the use of soft tissue of Perna viridis as a biomonitor of perylene bioavailability and contamination in coastal waters of Peninsular Malaysia.
\end{abstract}

Keyword: Distribution; PAHs; Perna viridis; Soft tissue; Mussel watch; Peninsular Malaysia 